\title{
Derivation Principle Dilemma and National (Dis)Unity in Nigeria: A Polycentric Planning Perspective on the Niger Delta
}

\author{
S. R. AKINOLA, Ph.D \\ (Development Planner \& Environmentalist) \\ Department of Architecture \\ Covenant University, Ota, Ogun State, Nigeria \\ Tel: 234-803-407-5110Ｅ-mail:srakinola@yahoo.com;
}

AYO ADESOPO, Ph.D

Department of Public Administration

Obafemi Awolowo University, Ile-Ife, Nigeria

Tel: 234-803-386-0944Ｅ-mail: aadesopo@yahoo.com

Received: July 3, 2011

Accepted: August 1, 2011

doi:10.5539/jsd.v4n5p251

\begin{abstract}
Military incursion into Nigerian politics unilaterally abrogated derivation principle that existed before the discovery of oil in commercial quantities and imposed an authoritarian and centralized fiscal system. The paper traces the poverty and human misery in the Niger Delta to three factors: (1) unresponsive government policy, (2) inadequate finance and (3) corruption and low public morality among government officials operating in the Niger Delta. The centralized fiscal system has acted as a set back on the progress of the Niger Delta where most of the country's revenues are derived. As expected, agitations for inclusiveness on the part of the people has led to several crises. In order to resolve the challenge of derivation and governance crisis in the Niger Delta, this paper derives some lessons from American federalism, Alaska's oil experience and Eastern and Southern African wildlife conservation programmes. Recent indications show that there exists robust and resilient associational life in the Niger Delta, which are imperative for igniting a shared community of understanding, and for valorizing the process of true federalism and democratisation in the region. Using polycentric institutional mechanism, this paper, therefore, proposes African Community-Initiatives and Development (ACID) Model for streamlining the activities and operations of formal institutions and self-governing institutions in the Niger Delta.
\end{abstract}

Keywords: Fiscal federalism, Derivation principle, Polycentric planning, Accountability

\section{Introduction}

The problem of ethnic minority has been receiving attention of scholars and practitioners of governance and development. This is because ethnic minority is usually sidelined and ignored by the majority in decision making and resources distribution. The consequence of such politics of exclusion has been agitation and demand for social inclusion, which at times by violent actions. Since society is a system of human cooperation, the question of how society can mainstream the minority groups in decision making on welfare matters requires adequate policy consideration. One of the three factors that is important in understanding how a society functions, as identifies by Tocqueville (1966), is the peculiar and accidental situation, which providence places people. This could refer to the environmental and material conditions that are available to people in fashioning their lives. The type of resources within an environment, to a large extent, other things being equal, determines the fortunes of the people in that environment.

Discussing resource management in a federation, it is pertinent to emphasize that it is a common pattern to experience constitutional wrangling, particularly on how resources should be shared among the constituent units. This cannot be unconnected with the fact that there are always poor and relatively rich units. The poor ones often prefer a re-distributive system of federal resource, while the richer or more endowed ones are in favor of more financial autonomy and revenue allocation based on the relative contribution of each constituent unit to the federal purse (Dunmoye, 2002:50). Consequently, to an extent, distribution should follow contribution and which of course should have a constitutional backing. Otherwise, distribution can be subjected to whims and 
caprices of subjectivity that may not take care of the interests of some citizens whose environment yields substantial revenues to the larger society - "Robbing Peter to pay Paul".

The distribution of revenue in Nigeria is at two levels. That is, vertically between the federal and state governments and later among the three vertical organs (federal/state/local governments) and horizontally among the component elements of each lower tier of government. The former is based on an approved revenue formula while the latter is based on a set of approved principles. Many of such principles have been applied since 1946 till date in the fiscal history of Nigeria. Between 1946 and mid-1960s, the three contending principles in the revenue sharing system in Nigeria were derivation, need and fiscal autonomy, with derivation principle the most prominent of the three. However, this pattern changed after the military intervention in politics in 1966.

Derivation principle implies that states should receive allocations from the central pool in strict proportion to their contribution to the pool (Ashwe, 1986:88; Okunrounmu, 1999:462; Abubakar, 1986:263). The philosophy behind this principle is that the residents of the area from where particular revenue is generated must have suffered one way or the other in terms of external costs, which manifest in the form of pollution, disruption of both social and economic life of communities and some other undesirable consequences arising from certain types of economic activity whether in manufacturing or in drilling for oil. Such people must be compensated by enabling them to benefit from the revenues generated in their community (Abubakar, 1986). This was the argument and practice as far back as the 1950s when revenues from cocoa (in the West) and groundnut (in the North) were particularly buoyant. This is also the argument today as advanced by the oil producing states of the Niger Delta.

The derivation principle, however, suffered a bastardisation, thus leading to a sharp decline from 100 percent in 1953 to 50 percent in 1960, 45 percent in 1969, 20 percent in 1975, 1.5 percent in 1982, 1.0 percent in 1990, 3.0 percent in 1992 and the current 13 percent which was fixed by section 162 (2) of the 1999 Constitution (Anyanwu, 1997:190; The Guardian September 12, 2000:53; Sagay, 2001; Rapu, 2006:13). The question is "What could have accounted for such a decline?"

Okilo (1980) states that derivation as a principle of revenue allocation has continued to be deliberately suppressed since crude oil became the mainstay of the country's wealth simply because the main contributors of the oil wealth are the minorities. In spite of the suppression, the Niger delta contributes over $40 \%$ to the Nigeria's GDP, about $90 \%$ of total annual earnings and about $80 \%$ of the national gross income (Federal Government of Nigeria [FGN] 2008: 212). Despite the population of the region (about 33.5 million) accounting for about $23.0 \%$ of the national population (FGN, op. cit:189), the Niger Delta communities where the crude oil is extracted generally suffer poverty, neglect, environmental degradation, denial of fundamental human rights and transport bottlenecks (Naanen, 1995; Obi, 2004:450; Akinola, 2008: 89). In the Niger Delta area, there are several minority tribes, such as the Ijaws (mostly in the 'riverine' area), the Ilaje, the Itsekiri, the Urhobo, and others. The predominant occupations of the people in the region are farming, fishing, hunting, weaving, mason, petty trading, bicycle transport, motor cycle transport, boat transport, etc. In spite of the much acclaimed Niger Delta Master Plan, the welfare of the people remains at low ebb, while their aspirations remain unfulfilled.

The current episode in the Niger Delta confirms that the only way to get the attention of those in power is to engage in violence (Note 1). The failed efforts of the federal government in the use of the Joint Task Force (JTF) and the drastic reduction in oil revenues due to militancy and criminality compelled the federal government to offer amnesty package to the militants for disarmament. Two questions arise here: (i) Why did government offer amnesty that the people did not demand for? (ii) Should government wait for violence before listening to community voices? Nonetheless, the amnesty is a welcome development that could enable the militants to participate as civilians and agents of positive change in oil communities.

This paper raises two fundamental issues - derivation and accountability. At the level of the elite, most debates/discussions have focused on derivation principle and agitation for more resources to be given by the federal government to the region. At the level of the non-elite is the craving by voiceless majority on how the present resources from the federal government could benefit the people in the areas of education, health, transportation, poverty reduction, economic empowerment, etc. This area of accountability is grossly neglected by most elite, who are only concerned with higher percentage of resource allocation. Incidentally, it is the poverty-ridden condition of the people that these elite use as the springboard and the basis for their agitations for more resources but less concerned with how resources benefit the people.

This paper is concerned with how to ensure that resources get to community level to benefit the people in oil communities and secondly to enable the region get appropriate share of resources from oil that is extracted from the area. Hence, the paper adopts a polycentric planning approach to the analysis of events in the Niger Delta. 
Polycentric planning is a deliberate act of setting up multilayered and multicentred institutional mechanism that regards self-governing capabilities of local communities as foundation for reconstituting order from the bottom up. It can also be described as the process of ordering the use of physical, human and institutional resources as well as engaging the citizens in contractual relations with the public authority (Akinola, 2008a and 2010).

This paper derives some lessons from American federalism, Alaska's oil experience and Eastern and Southern African wildlife conservation programme. Similarly, the paper considers robust and resilient associational life in the Niger Delta (Akinola, 2008) as an imperative building block for igniting a shared community of understanding and for valorizing the process of true federalism and democratisation in the region. In this respect, the paper adopts African Community-Initiatives and Development (ACID) Model (Akinola 2000; 2008a) that is strongly applicable to the Niger Delta to empowering the people economically and reducing poverty. Consequently, the paper designs institutional mechanisms that could bring the Niger Delta people into the main stream of socio-economic and political decisions at various levels of decision making, thereby synergizing the efforts of the state, oil companies and community institutions through bottom-up and integrative planning.

\section{Derivation Principle and the Niger Delta Crisis}

The application of Derivation Principle in Nigeria predated the discovery of oil. In the early 1950s, the Northern Legislators issued an 8-point demand as a condition for remaining in Nigeria and one of which goes thus:

that all revenue shall be levied and collected by the Regional government except customs revenue at the port of discharge by the Central Agency and paid to its treasury. The administration of the customs shall be so organized as to assure that goods consigned to the Region are separately cleared and charged to duty (Sagay, 2001:14).

This was prior to the discovery of oil in commercial quantity at Oloibiri in the present day Bayelsa State (in 1956) when groundnuts were available in the North for the sole benefit of the North, cocoa boom for Western Region, coal and palm produce for Eastern Region while the Midwest Region held on to her timber and rubber produce. At that time, no region was forced to contribute to a common purse to the benefit of other regions. This position was accepted by all regions, entrenched in both the Independence and Republican Constitutions of 1960 and 1963 respectively and maintained until the military took over power in 1966.

The regions were fiscally powerful because of the pattern of fiscal arrangements at that time. Regions were fully in control of personal income tax and retained $70 \%$ of mining rents and royalties and transfer the remaining $30 \%$ to the Distributable Pool Account (Alade et. al., 2003: 22). From 1966 till date, the fiscal arrangement has changed drastically partly due to the prolonged military rule that negatively affected the revenue potentials of the state and local government. For example, Decree number 13 of 1970 made the bulk of federally collected revenue to go to the Federal Government and reduced export duties that used to go to the states from $100 \%$ to $60 \%$ (Dunmoye, 2002:50). States share of revenue from duties on motor fuel and excise duties was also reduced from $100 \%$ to $50 \%$, while that of mining rents and royalties was reduced from 50 to $45 \%$ (Ashwe, 1986:34; Abubakar, 1986:303). Decree number 9 of 1971 made federal government the sole custodian and beneficiary of offshore petroleum rents and royalties.

According to Sagay (2001), as at 1960, much importance was not attached to mineral oil but major agricultural products (like cocoa, groundnut, cotton, hides \& skin and palm oil) as income earning sources which were then under the control of the major tribes and thereby making it easy for them to emphasize derivation. Consequently, the people of the Niger Delta commenced a struggle that graduated from one of survival to that which would enable them control their own destiny. The objectives of the struggle are: (1) to return the Niger Delta to sound ecological health so that it continues to provide sustenance to the present and coming generations; and (2) to decolonize the political and economic space of the region and therefore help return the resources to the people and the community. These agitations led to the setting up of the Willink Commission in 1958 to examine minority fears and make suggestions on how to address them. The Willink Commission invariably led to the setting up of the Niger Delta Development Board in 1962 but the Board did not achieve much until the civil war began in 1967.

On February 23, 1966, Isaac Jasper Adaka Boro, a revolutionary youth from Oloibiri led a group of other youths in the area to declare the secession of the Niger Delta People's Republic from Nigeria. Boro and many other youths were later arrested, tried and convicted for treason. But, with continued degradation of the Niger Delta environment and the perceived lopsided revenue sharing formula, the agitations and struggle continued. Ken Saro-Wiwa, the president of the Movement for the Survival of Ogoni People (MOSOP) and other eight Ogonis were killed by Abacha administration on November 15, 1995. 
Rather than serving as a deterrent, the hanging of Saro-Wiwa emboldened the youths of the Niger Delta to employ more forceful means in the struggle. Youths in various minorities (Ijaw, Itsekiri, Oron, Ilaje, Andoni, Urhobo, etc.) came up with Bills of Rights for their communities. These groups innovated the idea of resource control, which was an expression of disaffection against systematic downgrading of the derivation criterion in the revenue allocation system in Nigeria.

Sagay (2001) points out that the littoral and other southern states of Nigeria that clamoured for resource control did so within the tenets of true federalism. The argument is premised on the fact that in a true federal state, each government must enjoy the deserved autonomy to the extent that it will be able to conduct its own affairs without interference from any government. From the point of view of revenue generation, according to him, the fiscal system must be designed such that the component units where resources are situated should have a fair share of the benefits by ways of revenues, royalties, taxes and so on derivable from such deposits while also contributing to the maintenance of the central government. This is the practice in countries like the United States of America, Canada, Australia, New Zealand, India, Switzerland, Spain, Germany and so on. Resource control goes hand-in-hand with true federalism as recognized and implemented faithfully in the Independence and Republican Constitutions. These constitutions granted each region the required status to operate as a "self-governing" region by making adequate provisions that guaranteed the required economic independence to the regions.

The argument of the oil-producing states of the south-south always takes off from the tenets of federalism emphasizing the fact that the principle of ownership and control of resources by the states as being fundamental elements of fiscal federalism. To them, anything short of an adequately applied derivation principle makes it to be an instrument of domination, oppression and exploitation. Apart from this, the southern states believe that the derivation principle is the best for revenue sharing as it will assist in developing and diversifying the economy, reducing economic mismanagement, discouraging autocratic central government, reducing misplacement of priorities and over-politicization.

\subsection{National Political Reform Conference of 2005}

The issues of resource control and federalism were part of the critical issues that the National Political Reform Conference of 2005 was to resolve. However, the Conference ended in a stalemate with its inability to resolve the critical issues daunting Nigeria's existence as a political entity. The delegates of Niger Delta walked out of the conference in protest (The Comet, Wednesday, July 13, 2005, pp. 1 and 4) when their demand for the control of 25 percent and 50 percent (in the future) of revenue from oil and gas was not met (Nigerian Tribune, Monday, 27 June, 2005, p. 3).

Besides, the critical issue is the gap between the Niger Delta elite that attended the conference and the Niger Delta people whom they represented. The elite are alienated from the Niger Delta grassroots. The process of constitutional making, no doubt, has left deep gaps in the democratic process and consolidation. The argument is that as long as there are gaps between the elite who crafted the constitutions and the Niger Delta people, the constitutions can not reflect the wishes and aspirations of the people.

Discussions so far confirm that the people in the Delta region are not benefiting from the present allocation of 13 percent derivation fund, indicating that there is also the problem of corruption and low public morality among government officials who are indigenes of the region (Akinola, 2008:104). In view of this, the question that needs be addressed revolves around accountability of public officials. In other words, the question of how the fund allocated to the region will benefit the common man in the region should be addressed. Without addressing this fundamental problem, the resource control struggle that most groups in the region are involved, if successful, will not enhance the living conditions of the common man as the money would always end in private pockets. As long as the problems of unemployment, poverty and exclusion persist in the region, insurgency, revolutionary activities, violence and insecurity will continue to be heightened.

\subsection{The Niger Delta Militancy and Amnesty Program}

The rising violence in the Niger Delta led to a shortfall in oil revenue from average $\$ 330$ billion (US $\$ 2.2$ billion) monthly recorded in 2008 to about $\$ 150$ billion (US $\$ 1$ billion) in January 2009, which represents a 50 percent fall in the oil revenue flow compared to that of 2008 (Amanze-Nwachuku ,2009). Realizing the great loss to government purse, the federal government, in late June 2009, offered an amnesty for gunmen who would lay down their arms. Since the people did not demand for amnesty, such an offer was met with suspicion because other amnesties in the past have been tricks. Militants have laid down weapons - only to be arrested later.

The government amnesty ( - a two-month disarmament and demobilization programme) qualifies each militant willing to surrender $\$ 60,000$ (about $\$ 450$ ) per month to cover food and living expenses from August 6 to 
October 4, 2009. The Nigerian government earmarked N50 Billion for the program and took about 10,000 militants through a re-integration process for an unspecified period of time (Gilbert da Costa, 18 July 2009). Information has it that an average militant was getting a minimum allowance of about $\$ 100,000$ monthly from militant activities (Agbo, 2009: 22) which almost doubled what government offered for disengagement from the activities. Reactions emanating from various groups in the region confirmed that the amnesty package of the government in its current form did not respond to fundamental issues (Connors and Swartz, 2009; Thisday Newspaper, Thursday, August 6, 2009, p. 3) by way of socio-economic development of the area. Analysts and observers of events in the region expressed skepticism about the programme's workability, because in the first place the real militants were not involved in the amnesty plan; they were just like spectators.

Further to this, it was observed that, assuming the amnesty works by making life better for the disarmed militants, will that not be creating a pathway for jobless youths to go into militancy in future so that they can also be taken care of through amnesty programs? Beside these, fear was also expressed about the sustenance of the maintenance of the amnesty beneficiaries. These, no doubt, require critical reflections. Beyond these, it was the general opinion that without a restructuring that could redress the injustice in terms of development and bridge the credibility gap between the people of the area and government, amnesty program will be tantamount to fire brigade exercise and a waste of resources.

In view of these governance crises in the region, two issues arise for consideration, viz: The aborted National Political Reform Conference (NPRC) and public accountability in the region. By boycotting the conference, the delegates from the Niger Delta did not help the matter. Boycotting the conference is like using a weapon of blackmail which did not work because the people of the other geo-political zones that staged opposition against the demands of the Delta zone could use the same weapon against the Delta people in the future if the allocation is increased beyond $17.0 \%$ (Akinola, 2008b). One thing that needs be understood is that it might be difficult to get all the demands met at once. It is a matter that should be based on continuous discussions and negotiations. Discussions, dialogue and negotiations at the federal level could provide a shared community of understanding and more dividends by a way of allocation but at the local level, the people of the Niger-Delta should be concerned with how allocated resources are judiciously utilized to enhance the welfare of the people. Without addressing these two issues, the country is likely to be sitting on a keg of gun powder as agitation for more resources will continue vis-à-vis pillage and plundering. In order to avert bigger national crises, it is high time alternative solution to the country's crises was sought.

It is in the light of this that this article designs a new institutional arrangement that is capable of bringing all the stakeholders together for regular discussions and adoption of a workable strategy. It is believed strongly that community self-governance, which is inward looking and capable of bridging the gaps between Nigerian leaders and the Niger-Delta people needs to be adopted. The institutional arrangement will address two issues that are of great concern: (1) How stakeholders at various levels of government should operate under a truly federal system. (2) How elite and non-elite should operate in synergy at community level polycentrically. Notwithstanding the fact that Nigeria is today one of the world's top ten oil reserves, the concern of everybody now should be the fate of the Niger Delta in some years to come as its land and water bodies are being degraded at will because of a natural resource that can be exhausted.

\section{Theoretical Underpinning}

The term, "self-governance", according to Wunsch and Olowu (1995:15) has double connotation. The first is "Self", emphasizing the grounding of the polity in self-organizing capabilities and rights of the individual citizens and communities which compose it and the second is "Governance", emphasizing governing as an open and open-ended process dealing with the development of institutions which sustain many organizations rather than the single organization, rulership connotation of the term "government". These scholars described "Self-governance" as an alternative to the "Centralized state" because it is a polity where the people are able to seek and develop partnerships with one another in the development process, where they can fulfill their potential for self-organization at multiple levels on which they hold the legal rights and diverse resources to engage in collective action. Beyond this, citizens are empowered, individual choices protected and on the whole allowing for polycentric institutional arrangement. Wunsch (1995:274), describing self-governance further, posits that the logic of "self-governance" is also important in that it allows space for many access points and rule-based organizations which permit citizens to join with one another (also) to take collective action. It can similarly facilitate, according to him, many rule-based organizations which allow citizens to act in a mediating position between individuals and the sovereign actions of government. On the whole, it is thus "polycentric". 
Failure to distinguish between the concept of decentralization and self-governance and the resultant misapplication of the former at the expense of the latter did a major mishap to the foundation of African development process after independence. Decentralization does not mean the same thing as self-governance though the two may embrace one another if the operators are selfless and patriotic. It is possible for decentralization structures to accommodate the self-governing principle. However, post-independent African governments have tended to exclude the elements of self-governance from their concepts of decentralization and in effect weakening the political capacity and slowing down the socio-economic development of Africans. For instance, the number of Local Governments in Nigeria has increased astronomically from 301 in 1979, to 449 in 1987, to 589 in 1991 and to 774 in 1996. At present, the local government structure in Nigeria is centralized though within a decentralized system as there exists no interactive link (connection) between the local government and the local community.

While decentralization is state-centered and outward looking, self-governance is people-oriented and inward looking. Decentralization as a World Bank agenda, though regards local governments as participatory institutions, in practice it is more of extension of central government to the local level where bureaucracy and politics prevailed. In this version, the local government system is a field administration as its working mechanism lacks democratic value; it is a centralized system at the grassroots. Further, the decentralization and good governance of both the World Bank and African Development Bank have not properly recognized the missing link in African local government systems. Overwhelming evidence confirmed that most African countries operate a centralized local government within a decentralized system as these third tiers of government have no interactive link with community institutions. Evidence abound that decentralization across Africa is a failure as it lacks the mechanisms that could enable the people and their elite leadership to work together as citizens of the same country. Invariably, party patronage, embezzlement, improper use of council property and facilities, corruption and consequently poverty have been heightened (Ayee, 1999 and 2006:137; Makara, 2000; Devas and Grant, 2003; Golooba-Mutebi, 2004; Wunsch and Ottemoeller, 2004; Akinola, 2004; Olowu, 2006).

The self-governing principle was closer to pre-colonial systems of community governance in most parts of Africa as most communities were then autonomous in the conduct of their public affairs. The colonial structure had no option but to depend on people-managed system of administration that was on ground at that time. For example, the common feature among the three regions in Nigeria, according to Otite and Kawonise (1997:44), was that indigenous communities maintained their own indigenous structures and organizations (traditional institutions, age grades, community development associations or town unions and local organizations) for popular participation throughout the colonial and post-colonial periods. Seeds of the simultaneous existence of indigenous and non-indigenous areas of associational life were sown and cultivated during the periods. In the early 1950s across Africa, these people-oriented institutions achieved remarkable success at building basic infrastructure - roads, clinics, bridges, markets, parks, etc - some of which still exist today. In addition, they were responsible for such other services as water supply, forestry, agricultural extension and police (Hicks, 1961; Akinola, 2000 and 2004).

Shortly after independence, however, the pendulum swung to the other extreme. African governments, confident about the powers and potentials of central government departments to promote and mobilize development and to consolidate the positions of the ruling elite, abolished the local government structures that relied on the indigenous system of governance in its operations. The post-colonial African political elite conceived the state as the prime mover of development and this placed the state as the main provider of goods and services required by the people in all spheres of development, including agriculture and industrialization (Edigheji, 2004:92). The ruling elite did not encourage the development of the private sector as the latter was treated with suspicion.

As a result, the participation in governance of business associations, trade unions and broader civil societies was limited as the newly independent states regarded themselves as the main agents of socio-economic transformation. In particular, the civil society in Nigeria was not given any role in decision-making on matters that concerned the welfare of the people (Kew, 2004:128). There were no consultations between the leaders and the people in matters that pertained to the welfare of the people. Though the decade of the 1980s witnessed an unprecedented emergence of institutions of civil society, especially NGOs in Nigeria (IDEA, 2000) they could not democratize the Nigerian state. Instead, they were penetrated, subverted, confused and repressed by the military (Oyediran and Agbaje, 1999:310). For instance, during the military regimes of Babangida and Abacha (1985-1998), institutionalized corruption, divide and rule tactics, elimination and repression of critics, clamp down on oppositions were the norms of the day in Nigeria and in the Niger Delta in particular. 
In spite of the failure of African state in governance, African people have resorted to trusted institutional arrangement by building confidence and trust in one another. As we have been reminded by Olowu and Wunsch (2004), the people in a community collectively decide to create a new organizational structure for the common good to deal with matters that cannot be addressed via the existing mechanisms. In the process, they voluntarily transfer to the new entity the right and authority to exercise control over the actions of specific individuals in specific areas of communal life. Similarly, Elinor Ostrom and others have discovered that Hardin's "villager" has survived through a multitude of ingenious strategies using local governing systems. These community-based approaches have shown that it is possible to share the fruits of the commons without destroying them (Hickel, 2002:265).

Akinola (2008:89) shows that while some people have adopted a negative approach in the Niger Delta, using violent and confrontational means, others have revived their old traditions, rooted in collective action: through self-organizing and self-governing capabilities, have worked to meet the needs of their communities and have achieved some success in providing social services. This confirmed that social disparities among the Nigerian state, its oil partners, and the oil communities can be addressed if a new institutional arrangement that could use existing self-organizing and self-governing institutions as building blocks for reconstituting order from the bottom up is designed and implemented. In a federal system, with respect to oil, the stakeholders - governments (federal, state and local), oil companies, community institutions and various revolutionary groups - should operate as partners with equal standing in decision making arenas.

However, this section will not be complete without reference to the example of Alaska, an oil-rich environment where solutions to problems have been worked out by both the people and the government.

\subsection{Alaska's Experience}

The experience of the people of Alaska in United States of America is similar to that of the Niger-Delta in several ways. The Alaskans had experienced environmental pollution due to oil extraction as well as grinding poverty, hopelessness, and political turmoil that resulted when colonial powers or homegrown despots plundered a land of its wealth and pocketed the profits (Hickel, 2002:8). Considering the fact that their land came first, the Alaskans decided to put aside their disagreements on personal visions, ambitions and interests and made Alaska the Owner State by drafting constitution that would safeguard their own lands and resources, to solve their own problems, and to build an economy that benefits all.

The idea was born over 50 years ago by the Alaska's founding fathers and mothers. These ordinary people, chosen for their experience and wisdom rather than their party, carried along the people of their constituencies in their deliberations and in just three months, they wrote the best state constitution ever written (Hickel op.cit:71). This does not suggest that things went on smoothly with the Alaskans. Alaska people had had a disappointing experience in 1952, when the 23-million acre statehood bill failed. However, in 1956, it was a different story when they received a 100-million acre land grant and in 1958 Congress passed the Alaska Statehood Act. Alaska's Owner State is a model worth considering. The Owner State created in Alaska works, and the philosophy behind it has the potential to solve similar problems across the globe.

\section{Polycentric Planning and Fiscal Federalism in the Niger Delta}

Federalism is not just a form of government; it is a method for solving problems, a way of life. Its attributes are manifold. Its creation and maintenance depend upon intelligent artisanship shared by citizens in federal societies... (Ostrom, 1991:247).

Tocqueville (1966) identifies three factors to be important in understanding how a society functions. The first factor he identifies as "the peculiar and accidental situation, which providence" places people. The second factor is "the laws", which may refer to institutions - the working rules of going concerns. The third factor is the "manners and customs of the people". In assessing the importance of these factors relative to the causes which tend to maintain democracy in America, Tocqueville gives priority to the habits of the hearts and minds of the Americans. Relating to one another by covenantal methods might then be construed to be the most important factor in conceptualizing a federal system of governance. It is in such a context that the meaning of federalism needs to be examined in order to understand the relationship of federalism to democracy.

American federalism could be viewed as a system of government in which a serious effort has been made to come to terms with the possibility that people might, in some significant sense, "govern" and to avoid presuming that "the government" governs. Government "governs" in a limited sense; the people also govern (Ostrom, 1991:12-13). The foundation upon which American democracy rests is the people at the local level, and the picture is captured in the words of Tocqueville (1966): 
The township is the only association so well rooted in nature that whenever men assemble it forms itself...the community is the basic unit of collective organization...the people through experience of living together through successive generations work out arrangements among themselves for meeting the requirement of life.

He further declares that in democratic countries, the science of association is the mother of science; the progress of all the rest depends upon the progress it has made.

Abundant evidence also confirmed that African people in diverse ecological and cultural settings coordinate complex patterns of interaction with one another to resolve problems of daily life. Reminiscent of African experience, Ostrom (1991:18) argues that:

If Africans were to concern themselves more with covenanting with one another to form civil bodies politics, they would appreciate that African peoples draw upon diverse ways of conceptualizing patterns of order in their societies. There is as much to be learned from stateless societies as from those that emerged as "kingdoms" and "empires" before the intrusion of European empires. Modern democratic societies cannot be imposed from the top. They emerge as people learn to cope with the problems of collective organization associated with their shared interdependencies.

Recent indications show that there exists robust and resilient associational life in the Niger Delta (see Akinola, 2008), which are imperative for igniting a shared community of understanding, and for valorizing the process of true federalism and democratisation in Nigeria and the Niger Delta in particular.

All over the world, enlightened governments and international agencies have focused on and sponsored grassroots associations in order to reach the poor for full-fledged mobilization, welfare enhancement and poverty reduction. Their active involvement in the development process is the key to success. However, it needs to be pointed out that not all social organizations and coping mechanisms are constructive and worthy of consideration as building blocks, yet it is important to understand them if they are to be made constructive. This is why assessing the resources among ordinary people "on the ground" is fundamentally important (Sawyer, 2005:58).

In order to address the problems identified in this paper, an African Community-Initiatives and Development Model is proposed for adoption in the Niger Delta.

\subsection{African Community-Initiatives and Development Model (ACID)}

African Community-Initiatives and Development Model (ACID) is strongly applicable to the Niger Delta region (see Akinola 2008a). It is designed for empowering local people economically and reducing poverty. It streamlines the activities and operations of formal institutions (Ministry of Niger Delta, Niger Delta Development Commission, Oil companies) and self-governing institutions (community institutions, religious organizations, occupational groups, etc) using polycentric institutional mechanism in dealing directly with the people. In this respect, Akinola (2000:187) identifies four things that need to be done: (1) Compensation for the affected people, denoted by C; (2) Reclamation or renovation of derelict land, denoted by R; (3) Control of mining operation; and (4) Financial allocation formula that reflects/addresses the needs of the affected communities. The financial allocation formula is expressed as:

$$
\mathrm{F}=\mathrm{C}+\mathrm{R}+0.9 \mathrm{P} \quad \text {--------- Equation } \mathrm{I}
$$

Where,

$$
\begin{aligned}
& \mathrm{F}=\text { Financial allocation (fund to be given to a community) } \\
& \mathrm{C}=\text { Total cost of compensation to be given to all persons affected. } \\
& \mathrm{R}=\text { Cost of reclamation of the affected resources - land, water body, forest. } \\
& \mathrm{P}=\text { Cost of projects (non-capital intensive - dispensary, markets, culverts, etc.). }
\end{aligned}
$$

The government will be responsible for $90.0 \%$ of the cost of projects ( $0.9 \mathrm{P})$ in consideration with the cost of the next project on the priority list of a community. This excludes capital projects such as construction of roads, bridges, educational and health facilities. For this second category of projects that are capital intensive, government should bear the full cost.

For instance, in the first community; $\quad \Rightarrow \quad \mathrm{F}_{1}=\mathrm{C}_{1}+\mathrm{R}_{1}+0.9 \mathrm{P}_{1}$

$$
\begin{array}{llll} 
& \quad & \text { second community; } \Rightarrow & \mathrm{F}_{2}=\mathrm{C}_{2}+\mathrm{R}_{2}+0.9 \mathrm{P}_{2} \\
& \# & \mathrm{nth} \quad \text { community; } & \Rightarrow \mathrm{Fn}=\mathrm{Cn}+\mathrm{Rn}+0.9 \mathrm{Pn} \quad \text {---- Equation II }
\end{array}
$$

Because many communities are involved in a local government area, the equation becomes: 


$$
\mathrm{FL}=\sum_{\mathrm{i}=1}^{\mathrm{n}}(\mathrm{Ci}+\mathrm{Ri}+0.9 \mathrm{Pi}) \quad \text {-------- Equation III }
$$

Where, $\mathrm{n}$ denotes the number of communities in a local government area.

FL denotes total fund required at the local government level.

At the state level, the equation becomes:

$$
\mathrm{FS}=\sum_{\mathrm{i}=1}^{\mathrm{n}} \mathrm{FLi} \text {-------- Equation IV }
$$

Where, $\mathrm{FS}=$ Total fund needed at the state government level Similarly, at the regional level, the equation becomes:

$$
\mathrm{FR}=\sum_{\mathrm{i}=1}^{\mathrm{n}} \mathrm{FS} \text {-------- Equation } \mathrm{V}
$$

Where, $\mathrm{FR}=$ Total fund required at the level of the Niger Delta region.

\section{Source: Adapted from Akinola (2000:187).}

Using certain criteria such as (1) geographical location, (2) size, (3) completed projects, (4) on-going projects, and (5) future projects (in order of priority), government should identify active communities with self-help projects and pay them directly as suggested here. The federal government, through its agencies (MND and NDDC), should start with communities with completed projects by paying such communities $90.0 \%$ of project cost. The proposed scheme of contribution between the people and the government is suggested by Akinola (2000:186-187). According to the scheme, if a community development association (CDA) has completed a project using its own resources, situation report by community development officers at the local government, in conjunction with self-governing community assembly (SGCA), should be sent to the MND and NDDC. Thereafter, the federal government or its agencies should give $90.0 \%$ of the cost of the completed project to the community by releasing the money directly to the concerned CDA's account. To facilitate payment of grants to CDAs, each CDA should be required to open a bank account to that effect. The community can then use the government grant in addition to locally generated resources for a new project. The subvention/grant for the last project (on priority list) in a community can be used for the maintenance of already completed and functioning projects.

The application of this model on pilot scale would go a long way in enlightening decision makers on how to resolve the Niger Delta crisis. Similarly, it would help in resolving the derivation and resource control problems. This is because it is the actual amount of money needed for these projects at the community level that the federal government would be required to pay to each community. At the same time, this strategy would help in preventing pillage and plundering in the Niger Delta.

In view of the complex, complicated and hydra-headed nature of the Niger Delta crisis, challenges in the region have to be addressed from several fronts. In this regard, ACID should be applied in tandem with African Polycentric Information Networking (APIN) model, which is capable of creating networks between the leaders and the people for effective information sharing and communication (see Akinola, 2008c:188-189). At the same time, African Public Sphere Restructuring Model (APSRM) needs to be applied for the setting up SGCA for deliberation, collegiality, mutual trust, reciprocity and shared community of understanding (see Akinola, 2010). APSRM, in turn, derives inspirations and working mechanisms from ten (10) African development models which are: (1) African Development Institutional Mechanism (ADIM) for connecting all the stakeholders in development at various levels of decision making (Akinola, 2007a); (2) African Food Security Model (AFSM) for securing food for the citizens (Akinola, 2008d,c); (3) African Employment Generation Model (AEGM) for generating employment opportunities (Akinola, 2008c: 193-195); (4) African Conflict Prevention and Peace Building (ACPPB) for detecting and preventing conflict as well as building peace (Akinola, 2008c: 189); (5) African Sustainable Environment Model (ASEM) for conserving and protecting environmental resources (Akinola, 2008e); (6) African Road Triology (ART) for building cost effective and durable roads (Akinola, 1998); (7) African Electoral Reform and Democratisation (AERD) for inclusive democratisation (Akinola, 2008c:192-193); (8) African Local Economic Development Strategy (ALEDS) for enhancing economic growth through local industrialization and sustaining development (Akinola,2007: 233; 2008c:190-191); (9) African Polycentric Privatization Model (APPM) for distributing the benefits of economic growth among the citizenry (Akinola, 2007: 233); and (10) African Human Resources Development and Utilization Model (AHRDUM) for bridging the gaps between developers and 'utilizers' of human resources. 
It is suggested that some communities are selected for practical application and implementation of these models and ideas on a pilot scale. For governance and development strategy to benefit the people, the people must be part and parcel of decision making right from the onset and having regard to Tocqueville's study, the people should be able to modify the governing institutions as their situations change.

\section{Concluding Remarks}

Since federalism is a method for solving problems, it is important that the Niger Delta people, especially the elite, adopt polycentric arrangements, unite to resolve the issue of corruption and address specific challenges of daily life before demanding for more resources from the central government. Organisation is the weapon of the repressed in their struggles against the oppressors. It presupposes that people that agitate for fiscal federalism should first of all learn how to relate with one another in such a way that the fruits of the common trickle down to the people. Lack of a shared community of understanding and unity among the Niger Delta people, invariably, gives room for the non-oil producing zones to exploit the region.

The Niger-Delta people can learn several lessons from the Alaskans. The first thing the Niger Delta people need to do is to iron out their differences if only to be able to synchronize their demands and expectations. One other important issue to be addressed is the problem of ethical deficit and corruption among the Delta elite so that whatever allocation the region gets in the end will benefit the common man in the Delta region. When elite are able to demonstrate good accountability, the problem of violence and militancy will become easier to address. It needs be pointed out that the social structure that could facilitate the enthronement of good accountability is in existence in the Delta region (Akinola, 2008). What the representatives of the people in the region could do is to tap the social capital in the region. Though some of them have been turned into negative social capital, they could be transformed through new institutional arrangements as was done with members of Oodua People Congress (OPC) in Saki community in Oke-Ogun of Oyo State, Nigeria (see, for example, Akinola 2009). If self-governing community assembly (SGCA) could be set up in various communities in the Niger Delta, new working relationship among all interests and groups will develop (see Akinola, 2009). Essentially, if the ruling elite could ensure that the current 13 per cent allocation delivers in terms of provision and production of socio-economic infrastructure and employment opportunities, the Niger Delta elite can then resume negotiation at the next available opportunity to further press for their demands.

Lessons from Eastern and Southern African countries reinforce the need for the adoption of polycentric planning in the restive Niger Delta. Conventional wildlife policies to stem the tide of poaching in Eastern and Southern African countries became inadequate until wildlife departments searched for new approaches. Their exploration coincided with a more general trend in development studies to include local communities in the planning and management of natural resources to promote economic growth (The World Conservation Union, 1980). The actions taken in Eastern and Southern African countries include: (1) Returning some revenues derived from wildlife to rural communities; (2) Ensuring that local communities participate in the benefits to be gained from the presence or utilization of wildlife; (3) Inducing individuals away from their past practices and toward behaviours that conserve wild animals; (4) Providing economic goods such as employment and development projects; and (5) Aspiring to transform the would-be poacher into an individual with a sense of proprietorship over wildlife. Consequently, rather than continue their historic antagonism with wildlife scouts, rural residents assisted government efforts in monitoring and protecting the resource (Gibson and Marks, 2000:337).

Furthermore, for Nigeria to resolve the Niger Delta crisis and remain united, appropriate revenue sharing formula that respects revenue generation potentials of diverse ecological environments should be developed and adopted. Nigerian 'rentier' economy with fiscal dependency of state and local governments is a pointer to economic stagnation and retrogression. Derivation principle and diversification of economy are antidote for the present economic comatose and doldrums in Nigeria. This is because derivation principle provides the most rational, efficient and equitable principle for revenue decentralization in a federation. This will solve the serious incentive problems associating with a centralized and transfer-based system characterized by lack of fiscal discipline, laziness and corruption.

By allowing each state to tap the natural resources in its area will not only revitalize work ethics but will also encourage the spirit of enterprise and resourcefulness and consequently, jump-start the economy from its present static position. A good starting point is for the Federal Government of Nigeria to adopt these models and using multi-layered and multi-centred institutional mechanisms, implement polycentric planning strategies to address the Niger Delta crisis. In view of the relevance of polycentric planning to resolution of societal dilemma, any attempt to neglect it in the process of resolving the Niger Delta crisis will constitute a missed opportunity for the region and Nigeria as a country. 


\section{References}

Abubakar, I. H. (1986). Public Finance and Budgeting: Principles, Practice and Issues with Particular Reference to Nigeria. An Unpublished Manuscript.

Adedeji, Adebayo, and Otite Onigu (1997). Nigeria: Renewal from the Roots? The Struggle for Democratic Development. London and New Jersey: Zed Books.

Adesopo, A. A. and Asaju, A. S. (2005). "Nigerian Federation and the issue of Resource Control Right". In Feridun, Mete and Akindele, S.T. (Eds.) Nigerian Economy: Essays on Economic Development. North Carolina: Lulu Press Inc. pp. 621-648

Agbo, Anayochukwu. (2009). "Confusion Over Amnesty." Niger Delta: Why Amnesty Deal may fail. Tell Magazine, No. 28, July 13, 2009, pp. 20-25.

Akinola, S. R. (1992). Governance and the Deprived Group: A Case from Oil Producing Region of Nigeria. Journal of Nigerian Public Administration and Management 2(2):68-77.

(1998). Oil Prospecting, National Integration (Unity) and Sustainable Development in Nigeria. In S. S. Obidi, E. R. I. Afolabi, M. A. Adelabu, and S. V. Kobiowu. (Eds.) Book of Readings on Education, Environment and Sustainable National Development. Ibadan: Cardinal Crest.

(2000). Balancing the Equation of Governance at the Grassroots. In Adebayo Adedeji and Bamidele Ayo (Eds.) People-Centred Democracy in Nigeria? The Search for Alternative Systems of Governance at the Grassroots. Ibadan: Heinemann.

(2004). Local Self-Governance as an Alternative to Predatory Local Governments in Nigeria. International Journal of Studies in Humanities 1(3):47-60.

(2005). Structural Transformation and Polycentric Governance: Complementary Strategy towards Nigeria's Reform Agenda. Proceedings of the 14th general assembly of the Social Science Academy of Nigeria, pp. 238-250.

(2007). Knowledge Generation, Political Actions and African Development: A Polycentric Approach. International Journal of African Renaissance Studies 2(2):217-238.

(2008). Coping With Social Deprivation through Self-Governing Institutions in Oil Communities of Nigeria. Africa Today 55(1):89-107.

- Forthcoming. (2008a). Polycentric Planning and Community Self-Governance as Panacea to the Niger Delta Crisis. African Journal of Development (AJD). New York University, USA.

Forthcoming. (2008b). Community Self-Governance as a Panacea for Environmental and Social Injustice in the Niger-Delta of Nigeria. In Akin Alao and Rotimi Taiwo. (Eds.) New Frontiers in African Studies. African World Press and Red Sea Press.

(2008c). Alternative Planning Models for Development in Africa. In Knowledge to Remobilise Africa.

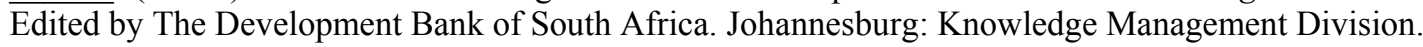

(2008d). "The Role of Covenant University in Ensuring Food Security and Employment Generation in Africa: The Polycentric Planning and Poverty Reduction Strategy (PPPRS)." A Proposal Submitted to The Chancellor, Covenant University, Ota, Ogun State, Nigeria, June 26.

(2008e). Reducing Environmental Degradation and Poverty through Environmental Governance in Nigeria. In S. Padmaja, N.C. Gautam and M. A. Ali. (Eds.) Environmental Impact Assessment Studies and Planning Perspectives. SultanBazar, Hyderabad: BS Publications.

(2009). The Failure of Central Policing and the Resilience of Community-Based Security Institutions in Nigeria. In Adekunle Amuwo, Hippolyt A.S. Pul and Irene Omolola Adadevoh. (Eds.) Civil Society, Governance and Regional Integration in Africa. Nairobi: Development Policy Management Forum (DPMF).

(2010). Restructuring the Public Sphere for Social Order in the Niger Delta through Polycentric Planning: What Lessons For Africa? Journal of African Asian Studies, Cornell University, Ithaca, NY, USA (Accepted and Forthcoming) 9(1\&2)

Alade, S. O.; Ebajemito J. O; Rapu S. C.; and Tule M. (2003). Fiscal Federalism and Macroeconomic Governance. In O. J. Nnanna, S. O. Alade and F. O. Odoko (Eds.) Contemporary Economic Policy Issues in Nigeria. Abuja: Central Bank of Nigeria.

Amaize, Emma (2 August 2009). “Amnesty - Participants Ask Militants Not to Surrender Arms.” . [Online] Available: http://allafrica.com/stories/200908031022.html (Accessed 4/08/2009).

Amanze-Nwachuku, Chika. (04.09.2009). "Niger Delta: Nigeria Loses \$24bn Oil Revenue in 9 Months." [Online] Available: http://www.thisdayonline.com/nview.php?id=140418 (Accessed 09/04/2009).

Anyanwu, J. C. (1997). Nigerian Public Finance. First Edition. Onitsha, Nigeria: Joanee Educational Publishers Ltd. 
(1999). Fiscal Relations Among the Various Tiers of Government in Nigeria. In Fiscal Federalism and Nigeria's Economic Development. Proceedings of the 1999 Annual Conference of the Nigerian Economic Society (NES), pp. 119-144.

Ashwe, C. (1986). Fiscal Federalism in Nigeria. Research Monograph No 46. Centre for Research on Federal Financial Relations, The Australian National University, Canberra.

Ayee, Joseph. (1999). Corruption, Decentralization and Local Development in Ghana. Governance 99(4):1-6.

.(2006). Accountability for Pro-Poor Local Governance in Africa. In Millet, K., Olowu, D, and R. Cameron (Eds.) Local Governance and Poverty Reduction in Africa. African Development Bank, the International Monetary Fund and the World Bank, Washington, D. C.

Connors, Will and Swartz, Spencer (August 5, 2009). "Nigeria's Amnesty Program Draws Criticism." AFRICA NEWS culled from The Wall Street Journal, page A7. [Online] Available: http://online.wsj.com/article/SB124942256930505875.html (Accessed 5/08/2009).

Devas, Nick and Grant, Ursula. (2003). Local Government Decision Making - Citizen Participation and Local Accountability: Some Evidence from Kenya and Uganda. Public Administration and Development 23:307-316.

Dunmoye, R. A. (2002). Resource Control: Which Way Forward? The Nigerian Social Scientist 5(1):49-53.

Edigheji, O. (2004). The African State and Socio-Economic Development: An Institutional Perspective. African Journal of Political Science 9(1): 84-104.

Federal Republic of Nigeria (FGN). (1995). Report of the Constitutional Conference. Abuja: National Assembly Press.

(2008). Sustainable Development in the Niger Delta - The Master Plan Road Map 2020 (1960-2007). A Consolidation of Democracy.

Gibson, C. A., and Marks, S. A. (2000). Transforming Rural Hunters into Conservationsits: An Assessment of Community-Based Wildlife Management Programmes in Africa. In McGinnis, M. D. (Ed.) Polycentric Games and Institutions: Readings from the Workshop in Political Theory and Policy Analysis. Ann Arbor: The University of Michigan Press.

Gilbert da Costa (18 July 2009). "Nigeria Says Amnesty Program Taking Shape." [Online] Available: http://www.voanews.com/english/2009-07-18-voa18.cfm (Accessed 22/07/2009).

Gilbert da Costa (25 July 2009). "Robberies, Kidnappings on Rise in Nigeria's Southeast." [Online] Available: http://www.voanews.com/english/2009-07-25-voa11.cfm (Accessed 27/07/2009).

Golooba-Mutebi, Frederick. (2004). Reassessing Public Participation in Uganda. Public Administration and Development 24:289-304.

Hickel, Walter J. (2002). The Crisis in the Commons: The Alaska Solution. Oakland, California: Institute for Contemporary Studies.

Hicks, U. K. (1961). Development from Below: Local Government and Finance in Developing Countries of the Commonwealth. Oxford: Clarendon Press.

IDEA. (2000). Democracy in Nigeria: Continuing Dialogue(s) for Nation-Building. International Institute for Democracy and Electoral Assistance, International Capacity-Building. Series 10.

Iwuchukwu, Francis. (27 May 2009). "Genocide-David-West on the Offensive." Daily Independent, Lagos, [Online] Available: http://allafrica.com/stories/200905270635.html (28/05/2009).

Kew, Darren. (2004). The Third Generation of Nigerian Civil Society: The Rise of Nongovernmental Organizations in the 1990s. In A. A. B. Agbaje, L. Diamond, and E. Onwudiwe (Eds.) Nigeria's Struggle for Democracy and Good Governance: A Festschrift for Oyeleye Oyediran. Ibadan: University Press.

Leba, Lles. (June 25, 2006). "Crude Oil As Scapegoat." Vanguard (Lagos). [Online] Available: http://allafrica.com/stories/200606260129.html (Accessed on June 26, 2006).

Makara, Sabiti. (2000). Decentralization for Good Governance and Development: Uganda's Experience. Regional Development Dialogue 21(1):73-92.

Nigeriafirst.org. (2006). "Resolution of Onshore/offshore Dichotomy" [Online] Available: http://www.nigeriafirst.org/printer_258.shtml (Accessed on 17/6/2009)

Naanen, B. (1995). Oil Producing Communities and the Restructuring of Nigerian Federalism: The Case of the Ogoni People. Journal of Commonwealth and Comparative Polities. 33(1):126-155.

Nigerian Tribune Monday June 27, 2005 p.3

Obi, Cyril I. (2004). Globalization in Nigeria's Oil Industry: Implications for Local Politics. In A. A. B. Agbaje, L. Diamond, and E. Onwudiwe (Eds.) Nigeria's Struggle for Democracy and Good Governance: A Festschrift for Oyeleye Oyediran. Ibadan: University Press. 
Okilo, Melford. (1980). "Derivation: A Criterion of Revenue Allocation" Being Paper Presented at the Postgraduate Seminar, Command Staff College, Jaji.

Okunrounmu, T. O. (1999). Policy Issues in Fiscal Federalism and National Development. In Fiscal Federalism and Nigeria's Economic Development. Proceedings of the 1999 Annual Conference of the Nigerian Economic Society, pp. 453-475.

Olowu, Dele (2006). Towards a Local Governance and Poverty Reduction Programme at the African Development Bank. In Millett, Karin, Olowu Dele and Cameron Robert (Eds.) Local Governance and Poverty Reduction in Africa..ADB, IMF \& The World Bank. Published for the Joint Africa Institute.

and James Wunsch. (2004). Local Governance in Africa: The Challenges of Democratic Decentralization. Boulder, Colo.: Lynne Rienner.

Ostrom, V. (1991). The Meaning of American Federalism: Constituting a Self-Governing Society, San Francisco, California: Institute for Contemporary Studies (ICS) Press.

Otite, O. and S. Kawonise (1997). The Case Studies in the National Context: An Introductory Note. In Adedeji, Adebayo and Onigu, Otite (Eds.) Nigeria: Renewal from the Roots? The Struggle for Democratic Development. African Centre for Development and Strategic Studies (ACDESS). London and New Jersey: Zed Books.

Oyediran, Oyeleye and Adigun Agbaje, (eds.) (1999). Nigeria Politics of Transition and Governance 1986-1996. Dakar: CODESRIA.

Rapu, S. C. (2006). Tax Assignment and Revenue Sharing in Nigeria: Challenges and Options. In Economic and Financial Review 44(1):1-44.

Sagay, Itse E. (2001). "Nigeria: Federalism, the Constitution and Resource Control" Text of speech delivered at the fourth sensitization programme organized by the Ibori Vanguard at the Lagoon Restaurant, Lagos on $19^{\text {th }}$ May, 2001 [Online] Available: http://www.waado.org/NigerDelta/Essays/ResourceControl/Sagay.html (Accessed on 5/26/2009).

Sawyer, Amos. (2005). Beyond Plunder: Toward Democratic Governance in Liberia. Boulder, Colorado: Lynne Rienner.

Suberu, R. T. (2001). Federalism and Ethnic Conflict in Nigeria. Washington DC: United States Institute of Peace Press.

The Comet Newspaper, Wednesday July 13, 2005 pp. 1\&4

The World Conservation Union. (1980). The World Conservation Strategy. Gland: The World Conservation Union.

Thisday Newspaper, Thursday, August 6, 2009 p.3

Tocqueville, A. (1966). Democracy in America. Vols. 1 and 2. Edited by Phillips Bradley. New York: Vintage Books.

Wunsch, James S. (1995). Beyond the Failure of the Centralised State: Towards Self-Governance and an Alternative Institutional Paradigm. In James S. Wunsch and Dele Olowu (Eds.) The Failure of the Centralised State: Institutions and Self-Governance in Africa. San Francisco, California: ICS Press pp. 270-292

and Olowu, Dele (eds.) (1995). The Failure of the Centralised State: Institutions and Self-Governance in Africa. San Francisco, California: ICS Press pp. 1-22

and D. Ottemoeller. (2004). Uganda: Multiple Level of Local Governance. In Olowu, D. and Wunsch, J. S. (Eds.) Local Governance in Africa: The Challenges of Democratic Decentralization. Boulder, Colorado: Lynne Rienner Publishers.

Note 1. According to the Nigeria Police, kidnappers and hostage takers in Niger Delta collected ransoms of over $\$ 100$ million between 2006 and January 2008 to release hundreds of foreign oil workers (Gilbert da Costa 2009). A total of 512 kidnappings have been reported so far this year, up from 353 in 2008 (Eboh 2009). Violence in the region accounted for the death of about 1,000 people between January and September 2008 (http://news.bbc.co.uk/2/hi/africa/7994152.stm (accessed 10/04/2009). 